\title{
A Framework For Linking Process Factors To Organisational Performance In A Government Department
}

Chengedzai Mafini, Vaal University of Technology, South Africa

David Rabolane Isaac Pooe, Vaal University of Technology, South Africa

\begin{abstract}
Organisational performance in the public sector in South Africa remains an issue of concern, due to the fact that most government departments continue to perform below the expected standard. This presented an impetus to conduct research on organisational performance in the sector on a continuous basis, in order to find current solutions. In this study, the relationship between organisational performance and four organisational process factors; namely, organisational structure, change, teamwork, and leadership in a South African government department was examined. A conceptual framework and four hypotheses which linked these four process factors and organisational performance were proposed. A six-section survey questionnaire was administered to 272 randomly selected members of a government department who were based in Gauteng Province. The proposed relationships were tested using a combination of Pearson's correlation coefficient and multiple regression analysis. Positive and statistically significant relationships were observed between organisational performance and the four process factors, leading to the acceptance of all hypotheses. The framework proposed in the study may be used in the diagnosis of performance problems in the public sector.
\end{abstract}

Keywords: Organisational Performance; Organisational Structure; Organisational Change; Organisational Leadership; Organisational Teamwork; Public Sector Organisation; South Africa

\section{INTRODUCTION}

$\mathrm{n}$ recent times, the world has been transformed into a global village which is characterised by numerous risks, uncertainties, and volatilities that compel organisations to seek for innovative strategies in order to ensure optimum performance (Flint \& Van Fleet, 2005). On one hand, numerous public sector organisations the world over suffer because their performance is so depressed that they cannot withstand the pressure (Acquaah \& Yasai-Adekani, 2008). On the other hand, through the generation and implementation of innovative strategies, many public sector organisations have managed to achieve satisfactory performance, which has enabled them to sustain their competitiveness and to survive during times of economic turbulence (Zane, Kane, \& Marcus, 2004). Underperforming public organisations are therefore compelled to develop strategies that could enable them to transform into high performance organisations with the view to survive and deliver high quality goods and services to their customers and clients (Molefe, Roodt, \& Schurink, 2011).

It may be argued that the public sector in South Africa is struggling to overcome the challenge of underperformance. It has also been suggested that outstanding organisational performance signifies that a public sector organisation is both effective and efficient in supplying public goods and services (Putu, Mimba, Van-Heden, \& Tillema, 2007). However, organisational performance as measured through service delivery has emerged as a source of frustration within the public sector in South Africa despite extensive initiatives to address it (Nilsson, 2010). Since public organisations generate most of their income from the fiscus, they are accountable to stakeholders such as the taxpayer and government (Fryer, Antony, \& Ogden, 2009). Consequently, immense pressure is placed on public organisations to positively transition their performance (Halachmi, 2011). In view of this, it may be useful to approach the challenge with a mind that is completely open to any possibilities. 
Against the above-discussed backdrop, this study examined the relationship between organisational performance and four organisational processes factors; namely, organisational structure, organisational change, organisational teamwork, and organisational leadership. There are a number of reasons why this combination of factors was selected for use in this study. Foremost, there is a need to consistently seek out ways of improving organisational performance in the public sector. Part of best practice in solving performance problems involves assessing the influence of the input resources, systems and/or the processes used to transform these resources into outputs (Gerhart, 2005). This implies that solving the performance problem may entail implementing substantive and appropriate modifications to the identified problematic inputs, systems or processes and ensuring that there exists an appropriate internal fit or alignment between them (Janssen, 2000). Furthermore, it was observed that there is a gap in the literature that addresses the combined influence of process factors on organisational performance within the specific context of the South African public sector, since the proposed conceptual framework is yet to be tested in this sector. For these reasons, the purpose of this study was to examine the interplay between organisational performance and four input process factors (organisational structure, organisational change, organisational teamwork, \& organisational leadership) in a South African public sector organisation. The study proposes a conceptual model that can be used in the diagnosis of performance problems in public organisations.

\section{LITERATURE REVIEW}

\section{Organisational Performance}

It is important to define organisational performance because failure to do so may result in the inability to measure or manage it (Artkinson \& Mcrindell, 1997). Scores of researchers and management practitioners have defined the concept of organisational performance using different viewpoints (Tait \& Nienaber, 2010). However, a common conceptualisation is that organisational performance comprises the actual output or results of an organisation as measured against its intended outputs (or goals and objectives) (Short, Ketchen, Palmer, \& Hult, 2007). A notable trend is that many public organisations in developing and emerging economies do not perform to the expected standard (Mankins \& Steele, 2005).

Organisational performance is a multi-dimensional construct that may be influenced by various factors (Wery \& Waco, 2004). A number of scholars (Ericksen \& Dyer, 2005; Katou \& Budhwar, 2007; Watson, Maxwell, \& Farquharson, 2007) attribute organisational performance to the quality or level of competency of human input. The Sactual volvesud 
organisational members (Nahm, Vonderembse, \& Koufteros, 2003). Zheng, Yang, and McLean (2010) define organisational structure as an indication of an enduring configuration of tasks and activities. It includes the nature of formalisation, layers of hierarchy, level of horizontal integration, centralisation of authority (locus of decisionmaking), and patterns of communication (Liao, 2007). From these conceptualisations, it can be presumed that no organisation exists without a structure and that organisational structures can be manipulated to achieve organisational goals.

Organisational structures may be classified as either mechanistic (inorganic), or organic (Hao, Kasper, \& Muehlbacher, 2012). In addition, organisational structures may also be sub-divided into five sub-dimensions which are the nature of formalisation, number of layers in hierarchy, level of horizontal integration, locus of decision making, and level of communication (Nahm et al., 2003). As suggested by Claver-Cortés, Pertusa-Ortega, and Molina-Azorín (2011) organisational structures are partially influenced by a constellation of considerations such as internal factors (e.g., purpose of the organisation and technological approach), external environment (e.g., socioeconomic and political factors), and individual choice factors (e.g., costs of becoming a member). On the other end, organisational structure may impact on a number of critical organisational factors such as inter alia organisational effectiveness (Schminke, Ambrose, \& Cropanzano, 2000), employee satisfaction and motivation (Gullov, 2006), innovation (Liao, 2007), financial performance (Koufteros, Nahm, Cheng, \& Lai, 2007) competitive strategy (Acquaah \& Yasai-Ardekani, 2008), effective communication and overall performance (Csaszar, 2008). The extensive influence of organisational 01 5]TJET41 001 ak7m[C)4(s)3(aszar)-5(,)]TJET[-)]TJET26 252 TmlET Tmß,a4 /P <</MCID 
Supportive synergy and departmental members' cohesion yields enhanced employee satisfaction and productivity (Buitenbach \& Witte, 2005). Organisational teamwork leads to the creation of a learning environment characterised by creativity (Acuna et al., 2009). Having friendly and helpful colleagues also contributes to enhanced organisational efficiency and performance (Kinicki \& Kreitner, 2003). A study conducted by Viswesvaran, Deshpande, and Joseph (1998) reports that there is a positive correlation between organisational flexibility teamwork. Customers and business partners may also find it easier to communicate with a team than with individuals (Salas, Sims, \& Burke, 2005). 


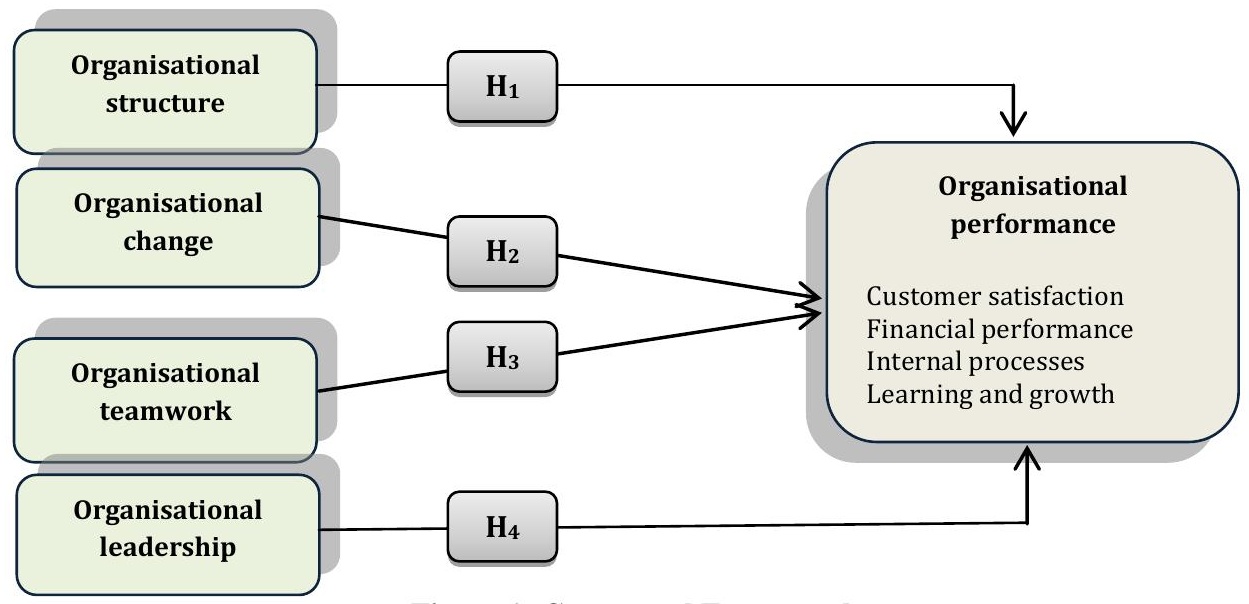

Figure 1: Conceptual Framework

\section{Organisational Structure and Organisational Performance}

Most of the literature seems to suggest that there exists a profound relationship between organisational structure and organisational performance. For instance, Schminke et al. (2000) argue that a decentralised organisational structure is conducive to the improvement of organisational effectiveness and performance. Decentralised structures also encourage more effective communication in addition to increasing employee satisfaction and motivation (Zheng et al. 2010). This could be attributed to the fact that in less centralised environments, the free flow of lateral and vertical communication is encouraged (Shafritz, Ott, \& Jang, 2005). Decentralised organisational structures also have a positive impact on other areas that include decision-making, responsiveness to market conditions and encouraging the adoption of innovation and higher levels of creativity (Sorensen \& Stanton, 2012). Conversely, high centralisation stifles interactions among organisational members (Gold, Malhotra, \& Segars, 2001), reduces, the opportunity for individual growth and advancement (Zheng et al., 2010), and inhibits innovative solutions to problems (Koufteros et al., 2007). Tsai (2002) encourages managers to ensure that they design lean, decentralised organisational structures in order to stimulate performance in their various organisations. Based on these empirical findings, one would expect a positive and significant association between organisational structure and organisational performance. Therefore, the following hypothesis is formulated:

$\mathbf{H}_{1}$ : There is a positive and significant relationship between organisational structure and organisational performance in a government department

\section{Organisational Change and Organisational Performance}

Literature is available that explains the possible effects of organisational change on organisational performance. For instance, Judge and Elenkov (2005) found that the organisation's capacity for change influences the environmental performance in that the higher that capacity, the more the organisation is able to perform in its operational environment. Properly implemented organisational change also facilitates process improvement, which in turn has a stimulus effect on organisational performance (Lee \& Ahn, 2008). Nordin (2011) also found that an organisation's preparedness for change is explained by factors such as emotional intelligence, organisational commitment, and transactional leadership behaviour. This suggests that an organisation's ability to change can only be enhanced when the identified factors are optimised (Liu \& Perrewe, 2005). Furthermore, Tsamenyi, Onumah, and Tetteh-Kumah (2010) observed that organisational change in various levels of the organisation positively influenced the post-privatisation performance of specific companies in Ghana. Palcic and Reeves (2010) also found that organisational change had positively impacted positively on the post privatisation performance of Ireland's national telecommunications operator, Telecom E'ireann. As such, planned organisational change is a fundamental process that should be expedited in order to enhance overall performance of the organisation (Diefenbach, 2005). The foregoing discussion presents meaningful a-priori reasons to affirm the existence of a positive and significant relationship between organisational change and organisational performance. Hence, the following hypothesis is proposed: 
$\mathbf{H}_{2}$ : There is a positive and significant relationship between organisational change and organisational performance in a government department

\section{Organisational Teamwork and Organisational Performance}

It has been observed that the outcome may be far better when employees work in a team rather than individually as every individual can contribute in his/her best possible way (Derby \& Larsen, 2006). Teamwork is also essential in organisations for better output and a better bonding among employees since tasks are accomplished at a faster pace when it is done by a team rather than by individuals (Salas, Sims, \& Burke, 2005). Additionally, a healthy competition usually exists among team members in addition to the improvement of relations among employees as well as the platform for team members to gain from each other (Morgan, 2010). Supportive synergy and organisational members' team cohesion yields enhanced job satisfaction, which is an essential element for accelerated employee and organisational performance (Buitenbach \& Witte, 2005). For this reason, organisational teamwork is an essential element for organisational success and must be encouraged if organisational goals are to be accomplished (Salas et al., 2005). Empirical results from a study conducted by Acuna et al. (2009) also reveal that working in a team is closely associated with the possibility to learn new things as well as job enlargement elements which have been found to be associated with increased organisational performance. In this context, it is logical to suppose that teamwork and organisational performance are positively and significantly associated. This leads to the following hypothesis:

$\mathbf{H}_{3}$ : There is a positive and significant relationship between organisational teamwork and organisational performance in a government department

\section{Organisational Leadership and Organisational Performance}

Research has established that there is a positive relationship between leadership and performance (Elenkov, 2002). Leadership, which involves both visionary and charismatic elements, is associated with higher performance, both for individuals, groups, and organisations across cultures and contexts (Sashkin \& Sashkin, 2003). Leadership behaviours cascade down through various organisational levels and have the effect of raising the degree of performance at every level. When employees are subjected to supportive leadership, their consciousness about the importance and value of goals is likely to be enhanced together with the ways that the employees can use to attain these organisational goals (Dasborough, Ashkanasy, Tee, \& Tse, 2009). This implies the leaders and followers will identify with the organisation's goals and work with a common purpose toward their attainment (Hancott, 2005). Furthermore, Huang (2006) advocates that leadership has a positive correlation with organisational performance. As such, without proper leadership, organisations are bound to fail (Brown \& Treviño, 2006). It may be envisaged then that a positive association between organisational leadership and organisational performance will be observed if the two factors are subjected to further empirical tests. Therefore, the following hypothesis is put forward:

$\mathbf{H}_{4}$ : There is a positive and significant relationship between organisational leadership and organisational performance in a government department

\section{RESEARCH METHODOLOGY}

This project was part of a larger study that was conducted in a South African government department. Management at the government department granted permission to conduct the research on the premise that department would benefit from the research findings. Survey questionnaires were administered in July 2012 with the aid of two trained research assistants who were employees of the department. Respondents were informed that they were participating in a voluntary study on organisational performance and were permitted to complete the questionnaires during working hours. Respondents completed a survey that included measures of demographics, organisational structure, organisational change, organisational teamwork, organisational teamwork, and organisational performance. Completed questionnaires were collected by the research assistants. During the collection of data, various ethical considerations that include the participants' right to anonymity, confidentiality, privacy or non-participation, informed consent and protection from discomfort, harm, and victimisation were adhered to. Given the ample support for the study from management and employees at the government department, 
the overall response rate in the study was $68 \%$. This response rate was acceptable because it satisfies Fincham's (2008) recommendation that response rates approximating $60 \%$ for most studies should be the goal of researchers in surveys.

\section{Respondents}

Respondents were composed of 272 management and employees of a South African government department. In the sample, 55\% $(\mathrm{n}=150)$ of the respondents were male and $45 \%(\mathrm{n}=122)$ were female. A majority of the respondents $(58 \% ; \mathrm{n}=185)$ were aged below 35 years. Employee tenure for the largest group of respondents $(74 \% ; \mathrm{n}=200)$ was less than five years. With regard to the type of employment, $82 \%(\mathrm{n}=223)$ of the respondents were permanently employed within the department. Approximately $43 \%(\mathrm{n}=117)$ of the respondents were holders of a first degree whereas $15 \%(n=40)$ of the respondents were holders of postgraduate qualifications. In terms of positions held, $1.5 \%(\mathrm{n}=4)$ of the respondents were executive managers, $7 \%(\mathrm{n}=18)$ were senior managers, $9 \%(\mathrm{n}$ $=24)$ were middle managers, $18 \%(\mathrm{n}=48)$ were line managers, $27 \%(\mathrm{n}=74)$ were specialist staff, $26 \%(\mathrm{n}=70)$ were clerical or administrative staff and $13 \%(\mathrm{n}=34)$ occupied other ancillary positions such as internships, security and general work.

In selecting the respondents, the simple random sampling technique was employed, which ensured that all entities within a population had equal chances of being recruited as respondents (Yates, Moore, \& Starnes, 2010). The size of the sample was determined using Green's (1991) rule of thumb which prescribes that no less than 50 participants are suitable for a correlation or regression with the number increasing with larger numbers of independent variables (IVs). In other words, for the current study which had four independent variables, the minimum acceptable sample size was 200 respondents. Additionally, the studies from which the questionnaire items were adapted were also used as general yardsticks in determining the sample size for this study.

\section{Measurement Scales}

The questionnaire that was used in this study was divided into six sections. Section A of the questionnaire elicited demographic information about the respondents. Section B used questions adapted from the Organisational Diagnosis Questionnaire (Preziosi, 1980) to elicit information on organisational structure. Section C used questions adapted from a study conducted by Korir, Mukolwe, Maru, and Korir (2011) to elicit respondents view's on organisational change. Section D elicited information on the existence of teamwork and Section E elicited information on respondents' views on leadership. Questions in Sections D and E were adapted from the from the Minnesota Satisfaction Questionnaire long-form (MSQ) designed by Spector (1985). Section F elicited information on organisational performance. Questions used in this section were adapted from studies by Jenkins, Gupta, Mitra, and Shaw (1998), Ittner, Larcker, and Meyer (2003), and Lau and Sholihin (2005). Likert scales anchored by $1=$ strongly disagree and $5=$ strongly agree were used from Section B to Section F.

\section{Validity and $\mathbf{R}$}




\section{Reliabilities and Operational Definitions}

The study sought to test the relationship between organisational performance and four process factors; namely, organisational structure, organisational change, organisational teamwork, organisational leadership. The reliabilities as well as the operational definitions for the factors examined in this study are reported in Table 1.

Table 1: Internal Consistency Estimates and Operational Definitions of Factors

\begin{tabular}{lcl}
\hline \multicolumn{1}{c}{ Factor } & Cronbach Alpha & \multicolumn{1}{c}{ Operational Description } \\
\hline Organisational structure & 0.803 & $\begin{array}{l}\text { This factor is concerned with the hierarchy of the organisation and } \\
\text { how the components of this hierarchy work together to achieve the } \\
\text { objectives of the organisation } \\
\text { This factor is concerned with processes in which the working } \\
\text { methods or aims or aims of an organisation are altered, for } \\
\text { example in order to develop and deal with new situations } \\
\text { This factor is concerned with the prevalence of joint actions by a } \\
\text { group of people, in which each individual subordinates his or her } \\
\text { individual interests to those of the group. } \\
\text { This factor is concerned with the extent to which authorities are } \\
\text { able to inspire and motivate their subordinates towards the } \\
\text { attainment of a common goal } \\
\text { This factor is concerned with the extent to which the organisation } \\
\text { is able to meet its goals }\end{array}$ \\
Leadership & 0.782 &
\end{tabular}

As reflected in Table 1, reliabilities for all five factors were acceptable since they ranged between 0.771 and 0.822, which is beyond the recommended minimum of 0.7 (Hair, Black, Babin, Anderson, Tatham, \& Black, 2010).

\section{CORRELATION ANALYSIS}

Person Correlation Coefficient was used to measure the degree of association between organisational performance and the four organisational process factors. The results of this analysis are encapsulated in Table 2.

Table 2: Correlation Analysis

\begin{tabular}{|c|c|c|c|c|c|c|c|}
\hline Factors & Mean & SD & 1 & 2 & 3 & 4 & 5 \\
\hline 1.Organisational Structure & 4.535 & 0.811 & 1 & & & & \\
\hline 2.Organisational Change & 4.523 & 0.737 & $.574^{* *}$ & 1 & & & \\
\hline 3. Organisational Teamwork & 4.657 & 0.713 & $.657^{* *}$ & $.552^{* *}$ & 1 & & \\
\hline 4. Organisational Leadership & 4.274 & 0.958 & $.639^{* *}$ & $.375^{* *}$ & $.596^{* *}$ & 1 & \\
\hline 5. Organisational Performance & 4.441 & 0.729 & $678^{* * *}$ & $.518^{* *}$ & $.570^{* *}$ & $.519^{* *}$ & 1 \\
\hline
\end{tabular}

Note: $\mathrm{N}=272: * *$ Correlation is significant at the 0.01 level (2-tailed). *Correlation is significant at the 0.05 level (2-tailed).

Table 2 reveals that the mean scores for the five factors ranged between 4.274 and 4.657 . These results demonstrate an average scoring between the 'agree' and 'strongly agree' positions in the Likert scale. Organisational teamwork scored the highest mean $(\bar{x}=4.657)$, which suggests that respondents were more satisfied with the levels of teamwork than the other factors. The correlation matrix also shows that there were positive relationships between the four factors and organisational performance $(0.519 \leq \mathrm{r} \leq 0.678)$.

\section{REGRESSION ANALYSIS}

In this study, regression analysis was employed to identify the variables that predicted or provided the best explanation for the portion of the total variance in the scores of the dependent variables (Malhotra, 2010). Since the Pearson correlations revealed positive associations, regression analysis using the 'enter' method was conducted with a view to establish whether or not causality exists between the dependent variable (organisational performance) and the independent variable (structure, change, teamwork, \& leadership). The results are reported in Table 3. 
Table 3: Regression Analysis

\begin{tabular}{|c|c|c|c|c|c|}
\hline \multirow{3}{*}{ Independent Variables } & \multicolumn{5}{|c|}{ Dependent Variable: Organisational Performance } \\
\hline & \multirow{2}{*}{ Beta } & \multirow{2}{*}{$\mathbf{T}$} & \multirow{2}{*}{ Sig } & \multicolumn{2}{|c|}{ Collinearity Statistics } \\
\hline & & & & Tolerance & VIF \\
\hline Organisational Structure & 0.433 & 6.510 & 0.000 & 0.619 & 2.367 \\
\hline Organisational Change & 0.153 & 2.784 & 0.006 & 0.612 & 1.634 \\
\hline Organisational Teamwork & 0.141 & 2.256 & 0.025 & 0.572 & 2.121 \\
\hline Organisational Leadership & 0.139 & 1.706 & 0.009 & 0.533 & 1.875 \\
\hline
\end{tabular}


accepted in this study. In line with these findings, Griffin, Patterson, and West (2001) stress that effective organisational teamwork contributes to improved performance of the organisation through enhanced employee satisfaction. Furthermore, organisational teamwork leads to greater cohesion between organisational members, which according to Turman (2003), acts as a catalyst in developing a sense of belonging. Organisational teamworking also has a positive impact on all four dimensions of performance namely, attitudinal, behavioural, operational, and financial (Delarue, Van Hootegem, Procter, \& Burridhe, 2008). When organisational teamwork is combined with structural change, performance can be further enhanced, as shown in a study conducted by Manzoor, Ullah, Hussain, and Ahmad (2011). It can therefore be suggested that organisational teamwork is an indispensible tool in cultivating high levels of organisational performance in any public organisation.

A strong positive correlation $(r=.519 ; \mathrm{p}<0,01)$ was observed between organisational leadership and organisational performance. In the regression analysis, organisational leadership was also statistically significant ( $\beta$ $=0.139 ; t=1.706 ; p<0.009)$. This result suggests that organisational performance increases or decreases according to the leadership processes within the organisation. Hypothesis $H_{4}$ was supported and is therefore accepted in this study. The fact that leadership has a significant impact on organisational performance is difficult to dispute. It has been observed that leadership directly influences individual employee performance (Walumbwa, Mayer, Wang, Workman, \& Christensen, 2011). This is important, since overall organisational performance is a summation of the performance of individuals within an organisation. Berson and Avolio (2004) found positive associations between leadership and the attainment of organisational goals. O'Reilly, Caldwell, Chatmanc, Lapiz, and Self (2010) linked organisational leadership to the effectiveness of overall strategy implementation. Organisational leadership is also an antecedent to organisational learning and innovation (Garcia-Morales et al., 2012). It thus becomes clear that organisational leadership and organisational performance cannot be disentangled from each other as there is an intense relationship between them.

\section{CONCLUSIONS}

The purpose of the study was to examine the relationship between organisational performance and four organisational process factors namely, organisational structure, organisational change, team processes, and leadership. Correlation and regression analyses conducted revealed that there were positive and predictive relationships between all four process factors and organisational performance, leading to the acceptance of all hypotheses that were suggested for the study. The positive and predictive relationship implies that the level of organisational performance in government departments either increases or decreases in line with, or is dependent upon the levels as well as the effectiveness of organisational structure, organisational change, team processes, and leadership. This study further extends the findings of previous studies conducted by Janssen (2000), Langley and Tsoukas (2010), and Gruchman (2009), which in varied contexts recognise the existence of a positive and significant relationships between similar organisational process factors and organisational performance.

The findings of this study are not without managerial implications for managers in the public sector. The study suggests that the four process factors examined are among key drivers of organisational performance in a public sector organisation. As such, the study provides a framework for diagnosis of performance problems in the public sector. As suggested by the widely acclaimed Mackinsey's $7 \mathrm{~S}$ framework (Michalski, 2011), the solution to performance problems in organisations is to find the most important drivers of performance, followed by making strategic improvements on them on a continuous basis. In the context of this study, improvement of organisational performance therefore hinges, in part, on the alignment of organisational structure and leadership to the goals of the public sector organisation. Well-planned and effectively implemented organisational change processes are also bound to improve performance. In the same vein, optimisation of teamwork processes is likely to yield a pertinent payback in terms of performance. Therefore, the conceptual framework suggested in this study may be adopted in efforts to improve organisational performance in the public sector.

\section{LIMITATIONS AND IMPLICATIONS FOR FURTHER RESEARCH}

The findings should be interpreted in line with the limitations associated with the study. One limitation pertains to the demographics of respondents. The restricted sample size $(\mathrm{N}=272)$ as well as the fact that respondents were based in one geo-spatial context attracts a limitation in terms of generalisation of the findings to 
the entire universe of work environments. A second limitation could be that the findings of the study were susceptible to common method bias, since a self-administered questionnaire was used to collect data from the respondents in the same period of time. However, to limit common method variance, the researchers systematically examined the construction of items in order to ensure that ambiguous, vague and unfamiliar terms were not included, and that the questionnaire as a whole and the individual items were formulated as concisely as possible (Chang, Van-Wittleloostuijn, \& Eden, 2010). Third, the general limitations associated with the quantitative approaches used in this study are acknowledged. Fourth, there are limitations associated with the questionnaire used in this study, since it was adapted from several questionnaires which were intended for purposes that differ from that of this study.

Similar to other research studies, this study has implications for further research. Similar studies using an amplified sample size or in other different geographic locations could be conducted in the future. Additionally, future research endeavours could examine the same topic using private sector organisations, which could facilitate comparisons of findings. The findings of the study may also be refined by using more robust statistical tools such as structural equation modelling. Additionally, since organisational structure and organisational leadership can be broken down into smaller sub-elements, future studies could also be conducted on the relationship between these sub-elements and organisational performance.

\section{AUTHOR INFORMATION}

Dr. Chengedzai Mafini, Faculty of Management Sciences, Vaal University of Technology, P. Bag X021 Vanderbijlpark, South Africa. E-mail: chengedzai@ hotmail.com (Corresponding author)

Prof. David Rabolane Isaac Pooe, Faculty of Management Sciences, Vaal University of Technology, P. Bag X021 Vanderbijlpark, South Africa. E-mail: pooe@vut.ac.za

\section{REFERENCES}

1. Acquaah, M., \& Yasai-Ardekani, M. (2008). Does the implementation of a combination competitive strategy yield incremental performance benefits? A new perspective from a transition economy in SubSaharan Africa. Journal of Business Research, 61(4), 346-54.

2. Acuna, S., Gomez, M., \& Juristo, N. (2009). How do personality, team processes and task characteristics relate to job satisfaction and software quality? Information and Software Technology, 51, 627-639.

3. Artkinson, A., \& Mcrindell, J. Q. (1997). Strategic management in government. CMA Magazine, 20-24.

4. Balogun, J., \& Johnson, G. (2004). Organizational restructuring and middle manager Sensemaking. Academy of Management Journal, 47(4), 523-549.

5. Banai, M., \& Reisel, W. D. (2007). The influence of supportive leadership and job characteristics on work alienation: A six-country investigation. Journal of World Business, 42, 463-476.

6. Bandow, D. (2001). Time to create sound teamwork. The Journal for Quality and Participation, 24(2), 4147.

7. Beachum, F. D. (2004). Leadership stability and principal turnover: A study of effects on school and student performance indicators. Paper presented at the University Council for Educational Administration Conference, Nashville, Tennessee, 27 May.

8. Berson, Y., \& Avolio, B. J. (2004). Transformational leadership and the dissemination of organisational goals: A case study of a telecommunication firm. The Leadership Quarterly, 15(5), 625-646.

9. Bloodgood, J. M., \& Morrow Jr, J. L. (2003). Strategic organisational change: Exploring the roles of environmental structure, internal conscious awareness and knowledge. Journal of Management Studies, 40, 1761-1782.

10. Boyne, G., Martin, S., \& Walker, R. (2009). Explicit reforms, implicit theories and public service improvement: The case of best value. Cardiff University, Local \& Regional Government Research Unit, Discussion Paper 4.

11. Brignall, S., \& Modell, S. (2000). An institutional perspective on performance measurement and management in the new public sector. Management Accounting Research, 11, 281-306. 
12. Brown, M. E., \& Treviño, L. K. (2006). Ethical leadership: A review and future directions. The Leadership Quarterly, 17, 595-616.

13. Buitendach, J. H., \& De Witte, H. (2005). Job insecurity, extrinsic and intrinsic job satisfaction and affective organizational commitment of maintenance workers in a parastatal. South African Journal of Business Management, 36(2), 27-37.

14. Burke, W. W., \& Litwin, G. H. (1992). A causal model of organisational performance and change. Journal of Management, 8(3), 523-546.

15. Burke, C. S., Stagl, K. C., Klein, C., Goodwin, G. F., Salas, E., \& Halpin, S. A. (2006). What types of leadership behaviors are functional in teams? A meta-analysis, Leadership, 17(3), 288-307.

16. Chang, S., Van-Witteloostuijn, A., \& Eden, L. (2010). From the editors: common method variance in international business research. Journal of International Business Studies, 41, 178-184.

17. Child, J. (2005). Organization. Oxford: Blackwell Publishing.

18. Clark, R. P., \& Harcourt, M. (2004). The determination of employee behavior. Research and Practice in Human Resource Management, 8, 61-71.

19. Claver-Cortés, E., Pertusa-Ortega, E. M., \& Molina-Azorín, J. F. (2012). Characteristics of organisational structure relating to hybrid competitive strategy: implications for performance. Journal of Business Research, 65, 993-1002.

20. Csaszar, F. A. (2008). Organizational structure as a determinant of performance: evidence from mutual funds. Strategic Management Journal, 33(6), 611-632.

21. Currie, G., \& Lockett, A. (2007). A critique of transformational leadership: moral, professional and contingent dimensions of leadership within public services organizations. Human Relations, 60(2), 341370 .

22. Dasborough, M. T., Ashkanasy, N. M., Tee, Y. J., \& Tse, H. M. (2009). What goes around comes around: How meso-level negative emotional contagion can ultimately determine organizational attitudes toward leaders. The Leadership Quarterly, 20, 571-585.

23. Delarue, A., Van Hootegem, G., Procter, S., \& Burridhe, M. (2008). Team-working and organisational performance: a review of survey-based research. International Journal of Management Reviews, 10(2), 127-148.

24. Derby, E., \& Larsen, D. (2006). Agile retrospectives: Making good teams great. London: Pragmatic Bookshelf.

25. Dickmann, M., \& Stanford-Blair, N. (2008). Mindful leadership: A brain-based framework (2 ${ }^{\text {nd }}$ ed.). Thousand Oaks, CA: Corwin Press.

26. Diefenbach, T. (2005). Different meanings of intangible assets and knowledge - and their implications for management and innovation. The International Journal of Knowledge, Culture and Change Management, 4, 127-142.

27. Dushon, D., \& Plowman, D. A. (2005). Nurturing the spiritual at work: Impact on work unit performance. The Leadership Quarterly, 16(5), 807-834.

28. Elenkov, D. S. (2002). Effects of leadership on organisational performance in Russian Companies. Journal of Business Research, 55, 467-480.

29. Ericksen, J., \& Dyer, L. (2005). Toward a strategic human resource management model of high reliability organisational performance. International Journal of Human resource Management, 16(1), 907-913.

30. Fincham, J. E. (2008). Response rates and responsiveness for surveys, standards, and the journal. American Journal of Pharmaceutical Education, 72(2), 43-55.

31. Flint, G. D., \& Van Fleet, D. D. (2005). A comparison and contrast of strategic management and classical economic concepts; definitions, comparisons, and pursuit of advantages. Utah: Utah Valley State College.

32. Fröbel, P., \& Marchington. M. (2005). Team working structures and worker perceptions: A cross-national study in pharmaceuticals. International Journal of Human Resource Management, 16(2), 256-276.

33. Fry, L. W., \& Matherly, L. L. (2006). Spiritual leadership and organisational performance. Paper Presented at the Academy of Management, Atlanta, Georgia, 22 February.

34. Fryer, K., Antony, J., \& Ogden, S. (2009). Performance management in the public sector. International Journal of Public Sector Management, 22(6), 478-498.

35. García-Morales, V. J., Jiménez-Barrionuevo, M. M., \& Gutiérrez-Gutiérrez, L. (2012). Transformational leadership influence on organisational performance through organisational learning and innovation. Journal of Business Research, 65(7), 1040-1050. 
36. Garvin, D. A. (1998). The processes of organisation and management. Sloan Management Review, 39(4), 33-50. Gerhart, B. (2005). Human resources and business performance: findings, unanswered questions, and an alternative approach. Management Review, 16, 174-185.

38. Green, S. B. (1991). How many subjects does it take to do a regression analysis? Multivariate Behavioral Research, 26, 499-510.

39. Griffin, M. A., Patterson, M. G., \& West, M. A. (2001). Job satisfaction and teamwork: The role of supervisor support. Journal of Organisational Behaviour, 22, 537-550.

40. Gruchman, G. B. (2009). The process-based view of a company: principles and applications- part 2. Business Process Trends, February.

41. Gold, A. H, Malhotra, A., \& Segars, A. H. (2001). Knowledge management: An organisational capabilities perspective. Journal of Management Information Systems, 18(1), 185-214.

42. Gullov, T. (2006). The evolving state-of-the-art. New York: Springer.

43. Hair, J. F., Black, B., Babin, B., Anderson, R. E., Tatham, R. L., \& Black, W. C. (2010). Multivariate data analysis: a global perspective. New York: Pearson.

44. Hancott, D. E. (2005). The relationship between transformational leadership and organisational performance in the largest public companies in Canada. (Unpublished doctoral thesis). Capella University, Canada, 15 June.

45. Halachmi, A. (2011). Imagined promises versus real challenges to public performance management. International Journal of Productivity and Performance Management, 60(1), 24-40.

46. Hao, Q., Kasper, H., \& Muehlbacher, J. (2012). How does organizational structure influence performance through learning and innovation in Austria and China. Chinese Management Studies, 6(1), 36-52.

47. He, Z. Y. (2009). Research on the structural relationship of primary school teachers in the teacher's beliefs, leadership behavior, classroom management strategies and classroom management performance. Journal of National Taichung University, 23(1), 99-127.

48. Hernes, T. (2010). Actor-network theory, Callon's scallops, and process-based organisation studies. In T. Hernes \& S. Maitlis (Eds.), Process, sensemaking \& organizing (pp. 161-184). Oxford University Press, Oxford.

49. Huang, L. S. (2006). Transformational leadership has effect on organisational performance: The organisational culture as an intermediary variable. (Unpublished Master's Thesis). National Taipei University, Taipei, Taiwan.

50. Ittner, C. D., Larcker, D. F., \& Meyer, M. W. (2003). Subjectivity and the weighting of performance measures: Evidence from a balanced scorecard. The Accounting Review, 78, 725-758.

51. Janssen, O. (2000). Job-demands, perceptions of effort-reward fairness, and innovative work behavior'. Journal of Occupational and Organisational Psychology, 73(1), 287-302.

52. Jenkins, G. D., JR., Gupta, N., Mitra, A., \& Shaw, J. D. (1998). Are financial incentives related to performance? A meta-analytic review of empirical research. Journal of Applied Psychology, 83, 777-787.

53. John, O. P., \& Benet-Martinez, V. (2003). Measurement: Reliability, construct validation, and scale construction. In H. T. Reis \& C. M. Judd (Eds.), Handbook of research methods in social psychology (pp. 339-369). New York: Cambridge University Press.

54. Judge, W. Q., \& Elenkov, D. (2005). Organisational capacity for change and environmental performance: an empirical assessment of Bulgarian firms. Journal of Business Research, 58(7), 893-901.

55. Lee, S., \& Ahn, H. (2008). Assessment of process improvement from organisational change. Information \& Management, 45(5), 270-280.

56. Liao, Y. S. (2007).The effects of knowledge management strategy and organisation structure on Innovation. International Journal of Management, 24(1), 53-60.

57. Liu, Y., \& Perrewé, P. L. (2005). Another look at the role of emotion in the organizational change: A process model. Human Resource Management Review, 15, 263-280.

58. Kaplan, R. S., \& Norton, D. P. (1996). The balanced scorecard: translating strategy into action. Boston, MA: Harvard Business School Press.

59. Katou, A. A., \& Budhwar, P.S. (2007). Human resource management systems and organisational performance: A test of a mediating model in the Greek manufacturing context. The International Journal of Human Resource Management, 17(7), 1223-1253.

60. Kinicki, A., \& Kreitner, R. (2003). Organizational behavior: Key concepts, skills and best practice. New York: McGraw-Hill. 
61. Kloot, L., \& Martin. J. (2000). Strategic performance management: a balanced approach to performance management issues in local government. Management Accounting Research, 11, 231-251.

62. Korir, J., Mukolwe, E., Maru, L., \& Korir, K. (2011). Change management effects on organizational performance of selected hotels in Nairobi, Kenya. International Journal of Social Science Tomorrow, 1(8), $1-7$.

63. Koufteros, X. A., Nahm, A. Y., Cheng, T. C. E., \& Lai, K. (2007). An empirical assessment of a nomological network of organisational design constructs: From culture to structure to pull production to performance. International Journal of Production Economics, 106(2), 468-492.

64. Langley, A., \& Tsoukas, H. (2010). Perspectives in process organisation studies, Oxford, UK: Oxford University Press.

65. Lau, C. M., \& Sholihin, M. (2005). Financial and nonfinancial performance measures: How do they affect job satisfaction? The British Accounting Review, 37, 389-413.

66. Malhotra, N. K. (2010). Marketing research: An applied orientation. (6 ${ }^{\text {th }}$ ed.) New Jersey: Prentice-Hall.

67. Malhotra, N. K. (2011). Basic marketing research (4 ${ }^{\text {rd }}$ ed.). Eaglewood Cliffs, NJ: Prentice- Hall.

68. Manzoor, S. R., Ullah, H., Hussain, M., \& Ahmad, Z. M. (2011). Effect of teamwork on employee performance. International Journal of Learning \& Development, 1(1), 110-126.

69. Morgan, G. (2010). Images of organizations. Thousand Oaks, CA: Sage.

70. Mcguire, D., \& Hutchings, K. (2006). A Machiavellian analysis of organisational change. Journal of Organisational Change Management, 19(2), 192-209.

71. Mankins, M. C., \& Steele, R. (2005). Turning great strategy into performance. Harvard Business Review: 65-72, July-August.

72. Marshak, R. J. (2005). Contemporary challenges to the philosophy and practice of organizational development. In D. L. Bradford \& W. Warner Burke (Eds.), Reinventing organizational development: New approaches to change in organizations. San Francisco, CA: Pfeiffer.

73. Michalski, A. (2011). The McKinsey 7-S Framework: Invented in the 1980s and still a possibility for success today. Munich: Grin Publishing.

74. Molefe, G. N., Roodt, G., \& Schurink, W. J. (2011). High performance organisation: a quantitative inquiry at a specific metropolitan municipality in the Gauteng Province. African Journal of Business Management, 5(3), 699-712.

75. Mwita, T. I. (2000). Performance management model: A systems-based approach to public service quality. International Journal of Public Sector Management, 13(1), 10-37.

76. Muijs, D. (2011). Leadership and organisational performance: From research to prescription. International Journal of Management, 25(1), 45-60.

77. Muijs, D., \& Harris, A. (2003). Teacher leadership: improvement through empowerment? An overview of research. Educational Management, Administration and Leadership, 31(4), 437-448.

78. Nahm, A. Y., Vonderembse, M. A., \& Koufteros, X. A. (2003). The impact of organisational structure on time-based manufacturing and plant performance. Journal of Operations Management, 21(3), 281-306.

79. Ndofor, H. A., Priem, R. L. Rathburn, J. A., \& Dhir, A. K. (2009). What does the new boss think? How new leaders' cognitive communities and recent "top-job" success affect organisational change and performance. The Leadership Quarterly, 20(5), 799-813.

80. Nilsson, J. (2010). What's the problem? Local officials' conceptions of weaknesses in their municipalities' crisis management capabilities. Journal of Contingencies and Crisis Management, 18(2), 83-95.

81. Nordin, N. (2011). The influence of emotional intelligence, leadership behaviour and organisational commitment on organisational readiness for change in higher learning institution. Procedia - Social and Behavioral Sciences, 29, 129-138.

82. O'Brien, R. M. (2007). A caution regarding rules of thumb for variance inflation factors. Quality \& Quantity, 41, 673-690.

83. O'Reilly, C. A., Caldwell, D. F., Chatmanc, J. A., Lapiz, M., \& Self, W. (2010). How leadership matters: the effects of leaders' alignment on strategy implementation. The Leadership Quarterly, 2, 104-113.

84. Oxtoby, B., Mcguiness, T., \& Morgan, R. (2002). Developing organisational change capability. European Management Journal, 20(3), 310-320.

85. Palcic, D., \& Reeves, E. (2010). Organisational status, change and performance: the case of Ireland's national telecommunications operator. Telecommunications Policy, 34(6), 299-308. 
86. Pan, Y., \& Jackson, R. T. (2008). Ethnic difference in the relationship between acute inflammation and serum ferritin in US adult males. Epidemiology and Infection, 136, 421-431.

87. Pierro, A., Cicero, L., Bonaiuto, M., Van Knippenberg, D., \& Kruglanski, A. W. (2005). Leader group prototypicality and leadership effectiveness: the moderating role of need for cognitive closure. The Leadership Quarterly, 16, 503-516.

88. Preziosi. R. (1980). Organizational diagnosis questionnaire. The 1980 annual handbook for group facilitators. New Jersey: University Associates.

89. Puspanathan, M., \& Lin, A. (2008). Leadership style and organisational performance in family owned small scale manufacturing industries in Sri Lanka. Paper presented at the International Colloquium on Business \& Management, University of Sri Jayewardenepura, Sri Lanka, March 27.

90. Putu, N. I., Mimba, S. H., Van Heden, J., \& Tillema. S. (2007). Public sector performance measurement in developing countries: a literature review and research agenda. Journal of Accounting and Organisational Change, 3(3), 169-177.

91. Pycraft, M., Singh, H., Phihlela, K., Slack, N., Chambers, S., \& Johnston, R. (2010). Operations management: global and Southern African perspectives ( $2^{\text {nd }}$ ed.). Cape Town: Pearson Education.

92. Sadeghi, D. (2011). Alignment of organisational change strategies and its relationship with increasing organisations' performance. Procedia Social and Behavioral Sciences, 20, 1099-1107.

93. Salas, E., Sims, D. E., \& Burke, C. S. (2005). Is there a big five in teamwork? Small Group Research, 36(5), 559-599.

94. Sandbakken, D. A. (2006). Leadership practices and organisational performance: A Norwegian study. Edamba Journal, 6, 19-12.

95. Sashkin, M., \& Sashkin, M. G. (2003). Leadership that matters. The critical factors for making a difference in people's lives and organisations'success. San Francisco: Berrett-Koehler Publishers.

96. Schminke, M., Ambrose, M. L., \& Cropanzano, R. S. (2000). The effect of organisational structure on perceptions of procedural fairness. Journal of Applied Psychology, 85, 294-304

97. Shafritz, J. M., Ott, J. S., \& Jang, Y. S. (2005). Classics of organization theory. Belmont, CA: Wadsworth.

98. Short, J. C., Ketchen, D. J., Palmer, T. B., \& Hult, G. T. M. (2007). Organisation, strategic group and industry influences on performance. Strategic Management Journal, 28(3), 147-167.

99. S Škerlavaj, M., \& Dimovski, V. (2006). Influence of organizational learning on organizational performance from the employee perspective: The Case of Slovenia. Management, 11(1), 75-90.

100. Smith, J. A., Morris, J., \& EzzameL, M. (2005). Organisational change, outsourcing and the impact on management accounting. The British Accounting Review, 37(4), 415-441.

101. Sorensen, L. J., \& Stanton, N. A. (2012). Y is best: how distributed situational awareness is mediated by organisational structure and correlated with task success. Safety Science, 12, 341-362.

102. Spector, P. E. (1985). Measurement of human service staff satisfaction: development of the job satisfaction survey. American Journal of Community Psychology, 13(6), 1-24.

103. Tait, A., \& Nienaber, H. (2010). Exploring the strategy to process gap: The case of four South African life insurers. Journal of Contemporary Management, 7, 271-289.

104. Tsamenyi, M., Onumah, J., \& Tetteh-Kumah, E. (2010). Post-privatization performance and organisational changes: Case studies from Ghana. Critical Perspectives on Accounting, 21(5), 428-442.

105. Turman, P. (2003). The impact of coaching techniques on team cohesion in the small group sport setting. Journal of Sport Behavior, 26(1), 63-81.

106. Vera, D., \& Crossan, M. (2004). Strategic leadership and organizational learning. Academy of Management Review, 29(2), 222-240.

107. Walumbwa, F. O., Mayer, D. M., Wang, P., Workman, K., \& Christensen, A. L. (2011). Linking ethical leadership to employee performance: the roles of leader-member exchange, self-efficacy and organisational identification. Organisational Behavior and Human Decision processes, 115 (2), 204-213.

108. Watson, S., Maxwell, G. A., \& Farquharson, L. (2007). Line managers' views on adopting human resource roles: the case of Hilton (UK) hotels. Employee Relations, 29(1), 30-49.

109. Wery, R., \& Waco, M. (2004). Why good strategies fail. Handbook of Business Strategy, 5(1), 153-157.

110. Whittington, J. L., Goodwin, V. L., \& Murray, B. (2004). Transformational leadership, goal difficulty and job design: independent and interactive effects on employee outcomes. The Leadership Quarterly, 15, 593606. 
111. Yates, D. S., Moore, D. S., \& Starnes. D. S. (2010). The practice of statistics (4th ed.). Gordonsville: Freeman.

112. Viswesvaran, C., Deshpande, S. P., \& Joseph, J. (1998). Job satisfaction as a function of top management support for ethical behavior. Journal of Business Ethics, 17(4), 365-371.

113. Zajac, E. J., Kraatz, M. S., \& Bresser, R. F. (2000). Modeling the dynamics of strategic fit: a normative approach to strategic change. Strategic Management Journal, 21, 429-453.

114. Zane, B., Kane, A., \&. Marcus, A. J. (2004). Essentials of investments (5 $5^{\text {th }}$ ed.). Boston: McGraw-Hill Irwin.

115. Zheng, W., Yang, B., \& Mclean, G. N. (2010). Linking organisational culture, structure, strategy, and organisational effectiveness: mediating role of knowledge management. Journal of Business Research, 63(7), 763-771. 